\title{
$\mathrm{Al} /$ サファイヤ常温接合体の引張り特性および 界面欠陥成長の有限要素法による解析
}

\author{
朴永朝* 榎学 須賀唯知岸 輝雄 \\ 東京大学先端科学技術研究センター \\ J. Japan Inst. Metals, Vol. 64, No. 8 (2000), pp. 684-690 \\ (C) 2000 The Japan Institute of Metals

\section{Tensile Properties and Analysis of Growth of Interfacial Defects by Finite Element Method in Al/Sapphire Joint Fabricated by SAB Process}

Young Jo Park*, Manabu Enoki, Tadatomo Suga and Teruo Kishi

Research Center for Advanced Science and Technology The University of Tokyo, Tokyo 153-8904

The generation of interfacial defects is an unavoidable problem in the room temperature bonding. For an application of this technology, it is important to elucidate the effect of interfacial defects on fracture behavior. Fracture mechanism and criterion were investigated using the $\mathrm{Al} /$ Sapphire joint known for easy control of bondability. The findings of this paper are summarized as follows. (1) Bondability at peripheral region appeared to be superior to that of central region, which was caused by higher compressive stress during the bonding. (2) The results showed clearly that the growth of interfacial defects is the dominant factor for the crack propagation and the location of fracture origin showed good agreement with the prediction made by the observation of as-bonded interface and by the calculation of stress field using FEM simulation. (3) A critical stress intensity factor for the growth of interfacial defect was also estimated by the analysis of FEM calculation and experimental observation.

(Received February 21, 2000; Accepted July 11, 2000)

Keywords: interfacial defect, fracture mechanism, fracture criterion, room temperature bonding, tensile test

\section{1. 緒言}

電子デバイスの高機能化や高精度化に伴い，その組立，実 装に打ける低温・低圧力化は重要な課題となっている1,2). 従来の一般化されている接合法である高温接合の場合，熱ひ ずみや熱応力の発生, 脆い反応層の形成, 接合可能な材料 . デバイスの制約といった問題が指摘される ${ }^{3-5)}$. 一方, 半導 体製造技術や表面分析技術の進展に伴って, 超高真空を積極 的に利用する加工技術が普及してきた結果, 接合分野でも機 能材料の複合化など実製品への適用を目指した技術の確立が 望まれるようになってきた. 表面活性化常温接合法 (Surface Activated Room Temperature Bonding : SAB)はその一つ で, 超高真空中で清浄かつ活性な表面を作製, コントロール し，それらを相互接触させることによって低ェネルギーでの 接合を実現する新技術として注目を浴びている ${ }^{6-8)}$. 期待さ れる応用例としては, 電子デバイス, パッケージングなどを 含むMEMS (Micro Electronic Memory System), 真空装置 のシーリングパーツ，また寿命を終えた後破棄されるような 一回の使用ではなく，接合と分離が自由自在な材料のリサイ クルを考えた, 可逆的 inter-connection ${ }^{9}$ 等の分野が考えら れる。

\footnotetext{
* 東京大学大学院生 (Graduate Student, Tokyo University)
}

しかしながら, 今までの研究は主に, 結合原理や接合強度 に関する接合条件の影響などの解明を中心として行われてき たため，破壊についてはまだ十分な知見が得られていない. 真空中での凝着現象の理解を目的として行われて来た，50 年代からの摩擦係数または付着係数の測定試験 と ${ }^{10-14)}$, 近 年になってようやく接合体の接合強度6)などが報告されてい る. 常温・低加圧 · 短時間といった常温接合プロセスの特徵 から, 接合面積率は被接合体の表面形状, 力学特性などの物 理的な因子に大きく依存するため ${ }^{15,16)}$ ，多くの場合界面欠陥 (未接合部)は避けられない，そのため破壊挙動に関する界面 欠陥の影響を明確にすることは，常温接合体の実用化を目指 す上で重要な課題になっている. この場合, 金属/セラミッ クスの異種材接合体では弾性係数の差に起因する混合モード 解析が必要される17,18). 異種材接合体で考慮すべき問題とし て, 同じく弾性係数の差に起因する変形拘束による多軸応力 状態が知られている19-22).

そこで, 本研究では他の系に比べて常温接合性に優れた $\mathrm{Al} /$ サファイヤ接合体を対象として, 先ほど指摘した異種界 面の問題に着目し, 欠陷を有する常温接合体の破壊源の位 置, 破壊機構および破壊クライテリオンの導出を試みた. 前 報のはく離試験 ${ }^{23)}$ に続き, 本報では引張り試験と有限要素 法による応力場解析を行い, はく離試験による結果との比較 検討も行った. 


\section{2. 試験片の作製および引張り試験}

\section{1 常温接合法による試験片の作製}

供試材として機械研磨执よび電解研磨した純度 $99.999 \%$ の 多結晶 $\mathrm{Al}$ とc一面研磨されたサファイヤを用いた， $\mathrm{Al}$ は圧 延板材から直方体比切出して，接合性括よび等方性を得る

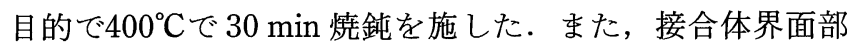
の応力場解析を容易にするため直方体の一端を円柱型に加工 して接合面とした。一方，サファイヤの方は厚さ $2 \mathrm{~mm} の$ 板を用いた．材料の形状，寸法执よび力学特性は Table 1 と 示した．両材を超高真空中で冷陰極型高速原子源 (Fast Atom Beam)照射によって表面を清浄化し，表面の再污染が 生じない条件を保って軸方向の圧力を加光接合体を作製し た。接合時間は $10 \mathrm{~min}$, 接合圧力は $\mathrm{Al}$ の降伏応力である $30 \mathrm{MPa}$ より低い $20 \mathrm{MPa}$ と，より高い $40 \mathrm{MPa}$ の二つとし た。以下それぞれ $20 \mathrm{MPa}$ 接合体, $40 \mathrm{MPa}$ 接合体と表記す る. 界面欠陥の大きさと空間的分布は透明なサファイヤ側か ら共焦点型レーザー顕微鏡 (CLSM)を用いて直接観察を行っ て測定した．詳細な作製プロセス，接合装置および接合界面 の観察結果は前報16) 報告した通りである。

\section{2 引張り試験}

引張り試験は直径 $4 \mathrm{~mm}$ の穴を開けたストッパーに接合 体のサファイヤを引っかけ $\mathrm{Al}$ を軸方向に引っ張る方法で行 った(Fig. 1)．負荷速度は $0.1 \mathrm{~mm} / \mathrm{min}$ と一定にした。この 際破壊過程を透明なサファイヤ側からのビデオマイクロスコ 一プで収録し，破壊源の位置抽よび破壊荷重を測定した。

$\mathrm{Al}$ の円柱型以外の部分はSUS304 タブを全体に付けて試験 を行った. 応力場の数值シミュレーションの際, $\mathrm{Al}$ 側の要 素は円柱型部分だけで行った。

\section{3. 圧縮変形および引張り負荷時の界面部応力場の数 值計算}

\section{1 圧縮変形のシミュレーション}

弾性体と弾塑性体との常温接合の場合, 接合面積率は弾塑 性体側の変形能に強く依存することが著者らによって明らか になっている(16)。従って, 円柱型 $\mathrm{Al}$ が平板サファイヤに対 して接合圧力で押されると，接合界面に沶いて半径方向に生 じる応力場によって欠陥構造も半径方向に変わることが予測
できる.シミュレーションのメッシュは 4 節点軸対称要素 で構成されて扣り, サファイヤは弾性変形, $\mathrm{Al}$ は加工効果 を示す弾塑性変形するものとした(Table 1)，異材間の圧縮 負荷による界面のすべり問題は摩擦形式, 摩擦係数扔よび着 脱条件を考慮する必要がある. 本研究では, 摩擦力は垂直力 と相対表面速度に支配される Coulomb モデルを仮定し, 摩 擦保数は金属とセラミックス間の理論值である 1 を用い た ${ }^{24)}$ またた，すべりによる節点の着脱を判定する分離力を 与光るパラメータである相対表面速度係数は相対表面速度の 100分の 1 とした。

\section{2 引張り負荷による界面欠陥の応力特異性の計算}

界面欠宿部の応力状態は汎用構造解析プログラムを用いた 数值シミュレーションによって求めた. 実験で測定された破 壊荷重での界面欠樎の応力拡大係数の導出は二つの段階で行 った．まず，界面欠宿のない完全接合体に执いて外部荷重に 上る界面部の応力場を計算した. 次に軸対称の中心に界面欠 陥を導入した要素を構成し, 実験の観察で判定された破壊源 の位置での応力が, 界面欠陥を導入した中心部にかかるよう に境界条件を与光た。即ち，予備計算を行い中心部が破壊応 力と一致する外部荷重を境界条件とした.これによって求め た界面欠陥の応力特異性を解析して界面欠陥の成長クライテ リオンである臨界応力拡大係数を導出した．この際界面欠陥 の塑性鈍化を避ける手段として，接合界面の $\mathrm{Al}$ 側には Fig. 2 亿示した模式図のような厚さ $h$ の $\operatorname{SSV}(Z$. Suo, C. F. Shih and A. G. Varias) モデルによる弾性層を導入した ${ }^{19,25)}$. 要 素の数は最大で4950個, 要素の一番短い長さは界面欠陥の 大きさの約 300 分の 1 であった(Fig. 3).

Table 1 Properties and size of materials.

\begin{tabular}{ll}
\hline \multicolumn{1}{c}{$\mathrm{Al}$} & \multicolumn{1}{c}{ Sapphire } \\
\hline Polycrystal 99.999\% & Single crystal (c-plane) \\
Specimen size & Specimen size $5 \mathrm{~mm} \times 10 \mathrm{~mm} \times 2 \mathrm{~mm}$ \\
total length $14 \mathrm{~mm}$ & Treated as elastic \\
cylinder part $\phi=3 \mathrm{~mm}, h=4 \mathrm{~mm}$ & $E=420 \mathrm{GPa}$ \\
Yield stress $30 \mathrm{MPa}$ & $\nu=0.2$ \\
Work-hardening $\left(\sigma=k \varepsilon^{n}\right)$ & \\
$k=179 \mathrm{MPa}$ & \\
$n=0.4$ & \\
\hline
\end{tabular}

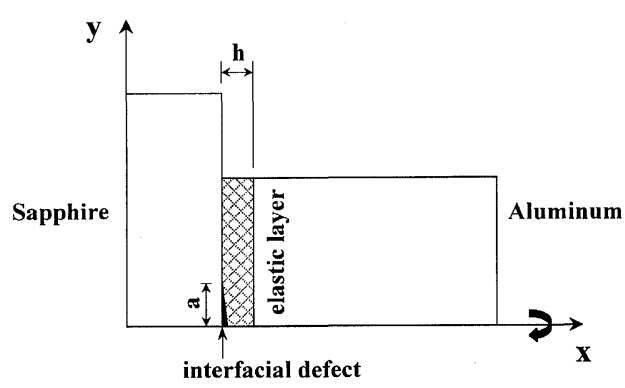

Fig. 2 Schematic illustration of SSV model for the calculation of stress state near the interfacial defect.

Fig. 1 Schematic illustration of tensile test. 

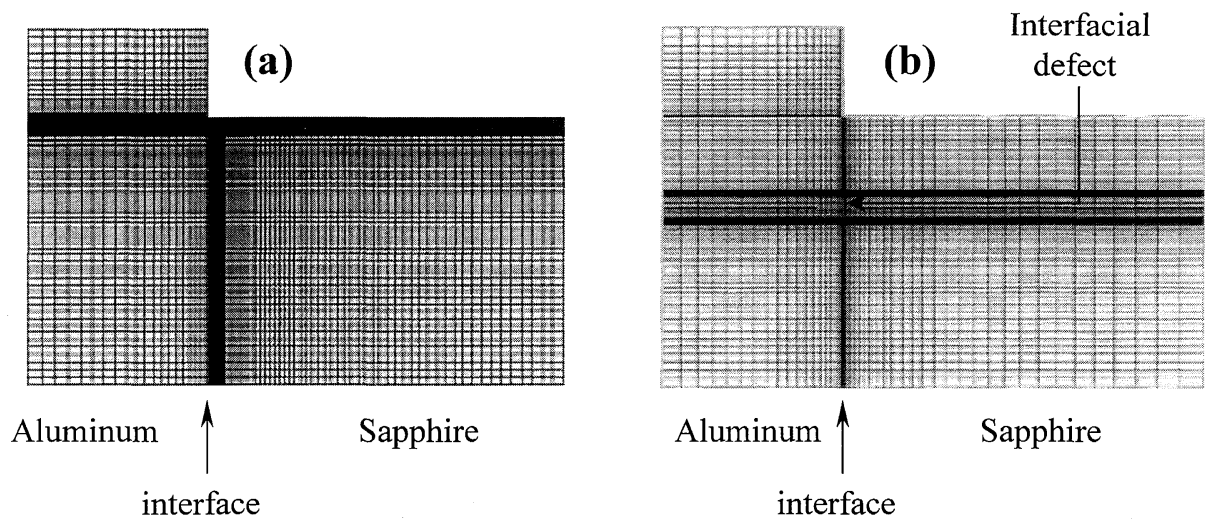

Fig. 3 Finite element model for a bimaterial joint.

(a) without interfacial defect, (b) with interfacial defect.
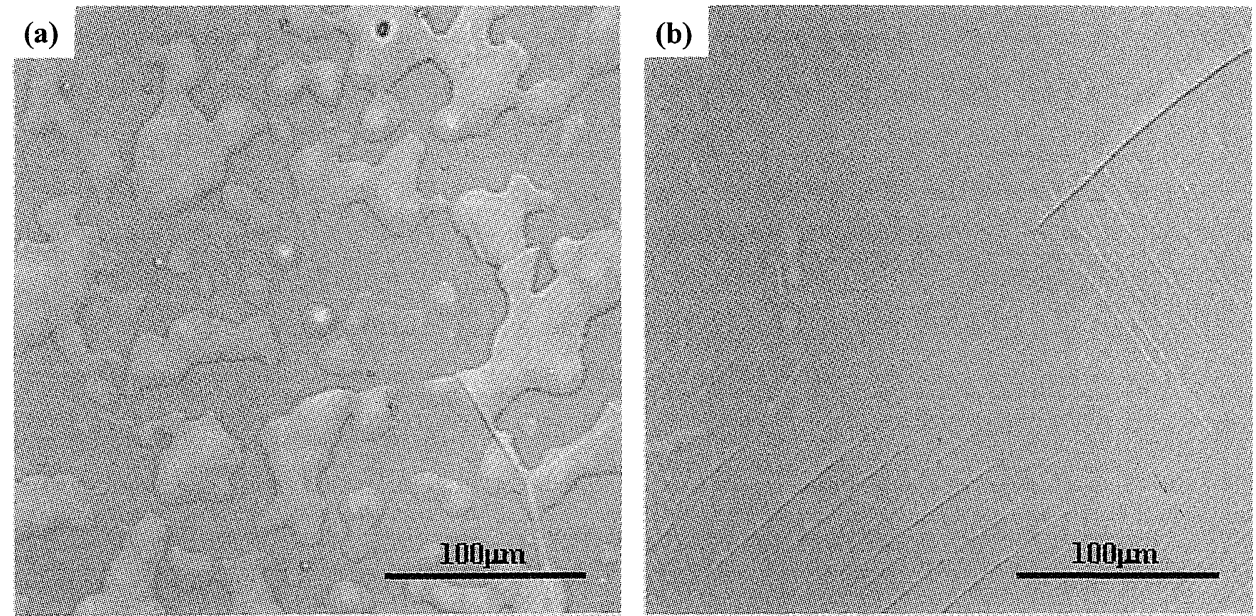

Fig. 4 Lasermicroscope observation of as-bonded joint.

(a) bonded at $20 \mathrm{MPa}$, (b) bonded at $40 \mathrm{MPa}$.

\section{4. 結果および考察}

\section{1 接合体の界面欠陥構造の観察および圧縮変形のシミュ レーション結果}

透明なサファイヤ側からの観察に上る接合界面の欠陥構造 をFig. 4 と示した.Fig. 4(a)は降伏応力以下で接合された $20 \mathrm{MPa}$ 接合体であり, 大きさ $10 \mu \mathrm{m}$ から $100 \mu \mathrm{m}$ 程度まで の界面欠陷が規則的に分布している。これと対して，Fig. 4(b) は降伏応力以上での $40 \mathrm{MPa}$ 接合体の場合は, 電解研 磨の選択性による粒界と接合圧力によるすべり線を除く領域 では良い接合性が認められた。レーザー顕微鏡観察によるコ ントラストの違いによる接合性を判断した. 5 カ所での平均 を取り，接合面積率はそれぞれ0.6と0.9程度に測定された。 接合面積率の数値シミュレーションによっても測定値と一致 する値が得られ，界面欠陥構造の制御が可能であることが示 されている16.

ところで，接合面積率の低い $20 \mathrm{MPa}$ 接合体では試験片 の中心部と周辺部が異なる欠陥構造を示すのが観察された. Fig. 5 は $20 \mathrm{MPa}$ 接合体の周辺部を観察したもので, Fig. 4(a)の界面欠陥を多く有する中心部に比べてほぼ欠陥のな

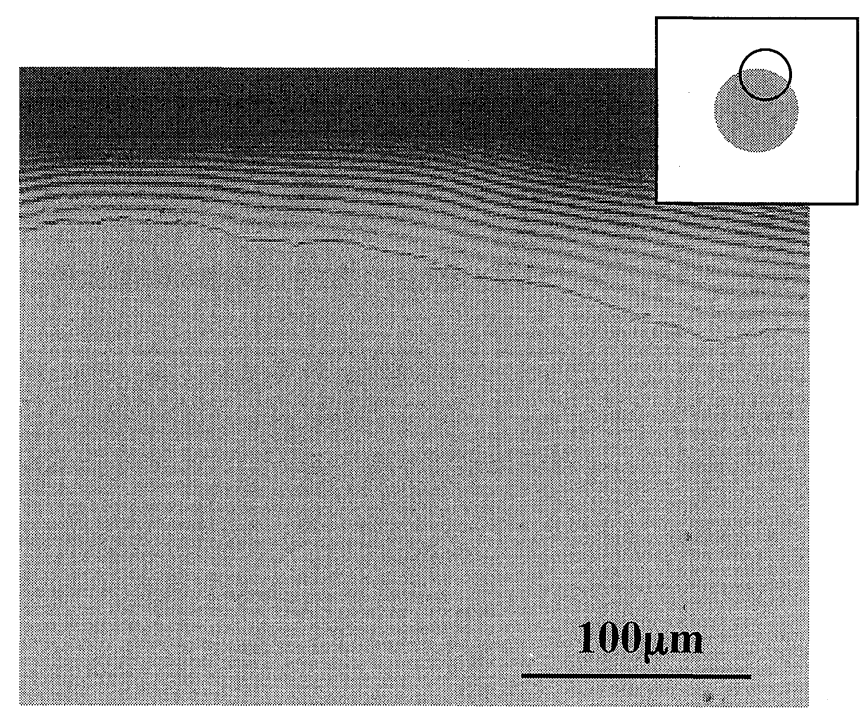

Fig. 5 Enhanced bonded area at the vicinity of periphery of bonded at $20 \mathrm{MPa}$.

いことが分かる. この半径方向の接合性の不均一の原因とし ては, 接合圧力を加えたとき周辺部で高い応力場が生じるこ とが考光られる．これを定量的に求めたシミュレーション結 
果をFig. 6 に示した. 図で横軸は $\mathrm{Al}$ 中心部から半径方向の 距離であり, 縦軸は界面の $\mathrm{Al}$ 側の積分点に括ける von Mises 応力を降伏応力で正規化した值である. 平らなサファ イヤに対して，A1の表面が平らな場合とのこぎり状の場合 に接合圧力 $20 \mathrm{MPa}$ および $40 \mathrm{MPa}$ の場合について計算を 行った. $20 \mathrm{MPa}$ をえたときの值は 1 より小さいもの の, 周辺部で高い分布を有することから, この部分では塑性 変形が中心部より起こりやすいことが推定された. また, 実 際の表面条件に近いと考兄られる, 粗さを有する場合の方が 平らな場合より中心部の接合性が高くなると予測された.

\section{2 引張り負荷による接合体の破壊挙動}

引張り試験に扣ける伸び率-荷重曲線を Fig. 7 に示した. $20 \mathrm{MPa}$ 接合体は伸び率が低い段階で破壊に至った. 破断面 の観察から界面欠陥を破壊源とする典型的なディンプル延性 破壊機構によることが分かった。一方，40 MPa 接合体の場 合は最高荷重 $\mathrm{S}_{\mathrm{u}}$ で $\mathrm{Al}$ 母材にくびれが生じ，接合体の強度

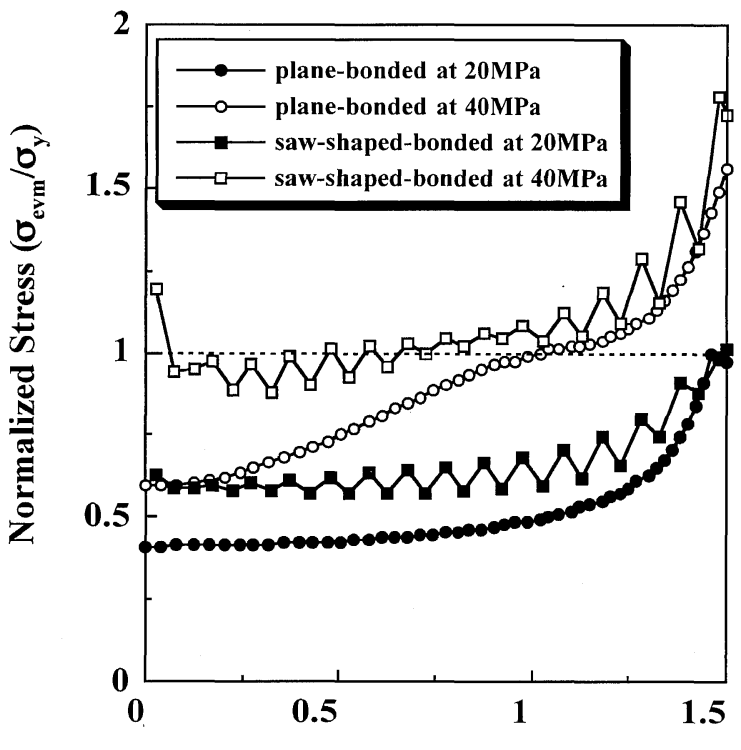

Distance from the Center, $l / \mathrm{mm}$

Fig. 6 Radial distribution of equivalent von mises stress for the compression of deformable body against plane rigid body. ( $\sigma_{\text {evm }}$ : equivalent von mises stress, $\sigma_{\mathrm{y}}$ : yield stress)
は $\mathrm{Al}$ 自体の強度に支配された。図の縦軸を応力ではなく荷 重で表した理由は，不完全接合のため実際の界面部応力を一 義的に決められないからである. Fig. 8 の(a)と(b) は 20 $\mathrm{MPa}$ 接合体のビデオマイクロスコープによる, Fig. 7 に記 した最大荷重 $\mathrm{A}$ 点と破壊進行中 $\mathrm{B}$ 点に相当する荷重での破 壊の様子である．白いコントラストは界面欠陥の成長部分で あり，黒いコントラストはまだ接合されている部分である.

図で 01,02 は第 1 破壊源，第 2 破壊源であり，破壊の進展 方向は矢印で表した。はく離試験23)扣よび $\mathrm{AE}$ 原波形解析 結果 ${ }^{26)}$ から明らかになったように，破壊開始の前に界面欠 陥の成長が先行することが観察された。 また，破壊源の位置 は界面欠陥が多く分布している中心部ではなく，やや周辺部 寄りであることが判明した。 そこで，引張り荷重を加えたと きの応力状態を調べ，その解明を試みた。

Fig. 9 は外部荷重が $\mathrm{Al}$ の降伏応力以下の場合 $(25 \mathrm{MPa})$, 降伏応力以上の場合 $(40 \mathrm{MPa})$ 打よび破壊荷重を $\mathrm{Al}$ の全面 積で割って得られた見かけ上の破壊応力 $(45 \mathrm{MPa})$ に扣い て, 完全接合体に対する引張り応力と平均応力の分布の計算

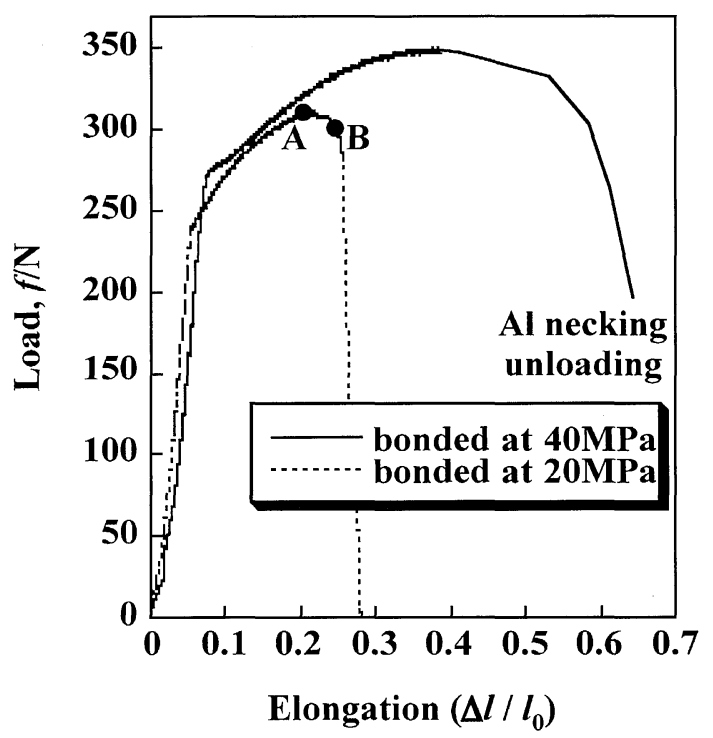

Fig. 7 Comparison of load-elongation behavior of joints bonded at $20 \mathrm{MPa}$ and $40 \mathrm{MPa}$. Joint bonded at $20 \mathrm{MPa}$ fractured at the interface and joint bonded at $40 \mathrm{MPa}$ showed necking at bulk of Al.
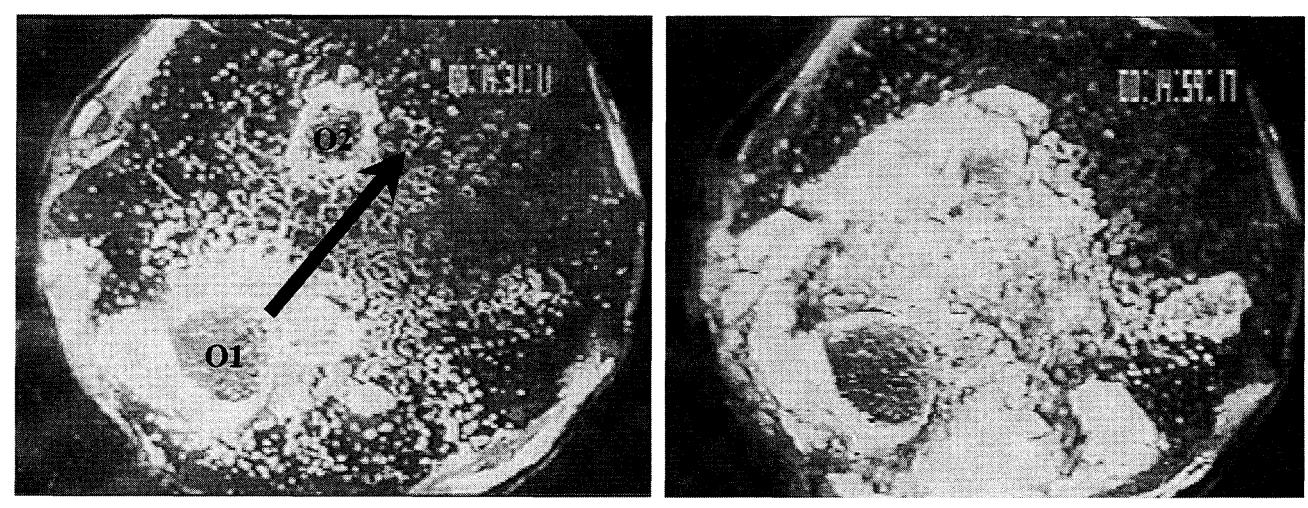

Fig. 8 Video-microscope observation of fracture origin.

(a) point A at Fig. $6(\mathrm{load}=310 \mathrm{~N})$, (b) point B at Fig. $6(\operatorname{load}=300 \mathrm{~N})$. 


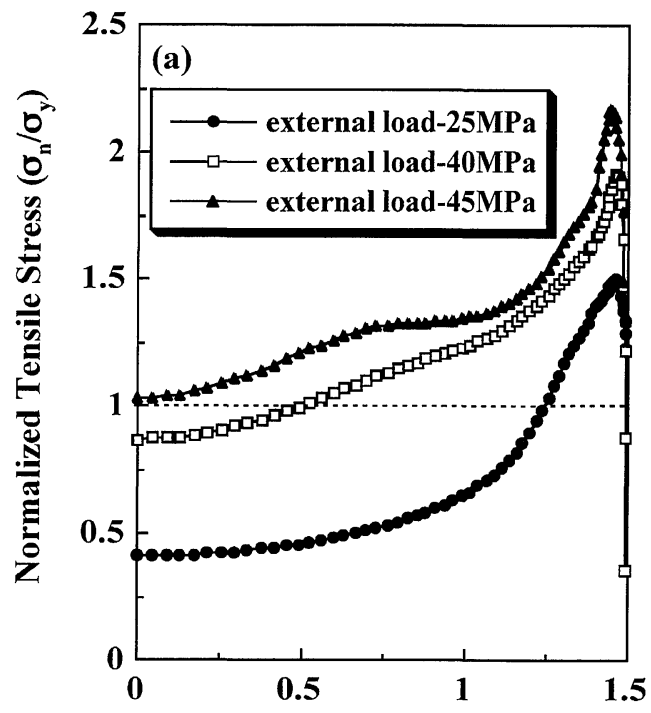

Distance from the Center, $l / \mathrm{mm}$

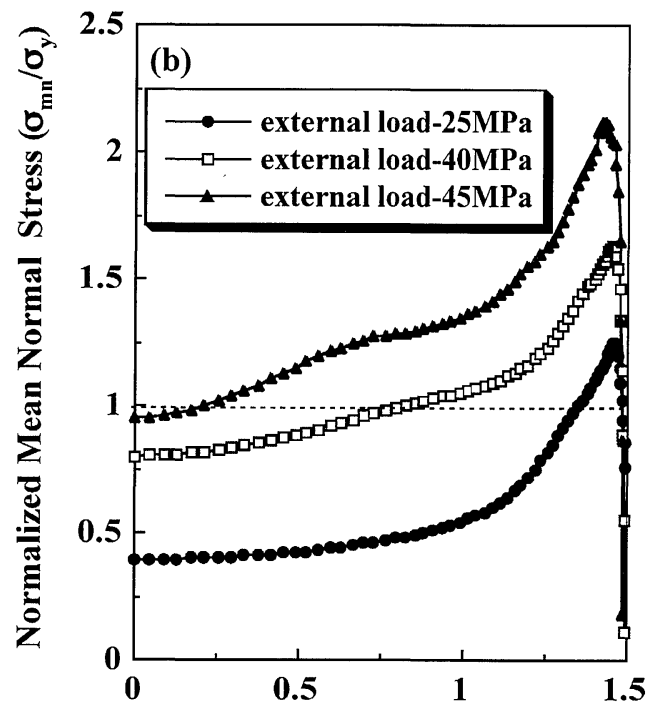

Distance from the Center, $l / \mathrm{mm}$

Fig. 9 Distribution of tensile and mean normal stress at the interfacial region developed by external tensile loading. (a) tensile stress, (b) mean normal stress.

結果である，両方とも界面端近傍で最大值を示し，さらに破 壊が観察された界面部の応力状態を数值でプロットした. 図 (a) と図(b)はとれぞれ接合体の中心から半径方向の引張り 応力と平均応力を $\mathrm{Al}$ の降伏応力で正規化した值を示したも のである.両方とも中心部で低く界面端近傍で最大值を有 し，見かけ上の破壊応力である外部負荷 $45 \mathrm{MPa}$ のとき降 伏応力の約 2 倍になっている. 実際観察された破壊源の位 置は応力場の最大值のところより内部側であったが，これは 前節で考察したように周辺部には界面欠陥が注涪存在しない 完全接合が得られていることが考兄られる。一方，弾性率の 高い材料に拘束され塑性変形しにくい状況の場合, 柔らかい 材料の方に大きい多軸応力状態が発生する. この際, 平均応 力/降伏応力で表される応力多軸度の值が臨界值に達すると, 低ひずみを示すディンプル延性破壊が生ずることが知られて いる19,211. 臨界多軸応力度は両材の力学特性招よび負荷方式 によって決まる状態量であるが，一般に約 4 程度が報告さ れている ${ }^{22)}$. 図(b)から本研究の接合体では多軸応力度が最 大で約 2 程度であるため, 完全接合体に近い $40 \mathrm{MPa}$ 接合 体では母材の塑性不安定に上る破壊が多軸応力に上る破壊に 優先したことが説明できた。

\section{3 界面欠陥の応力特異性による界面欠陥成長のクライテ リオン}

破壊源の位置と破壊荷重のデータを用いて界面欠陥成長の 臨界応力拡大係数の導出を試みた，この際，軸対称要素で界 面欠陥を中心に持ってくることによって実際の形状である円 盤型き裂の解析ができた．破壊源の位置はビデオマイクロス コープ観察から中心から約 $1 \mathrm{~mm}$ の距離であり, 見かけ上 の破壊応力(45 MPa)がかかったとき破壞源の界面部応力は $40 \mathrm{MPa}$ 程度と計算された(Fig. 9(a)). そこで, 中心部が $40 \mathrm{MPa}$ になるように境界条件を求めて, 界面欠陥を導入し た要素構成で界面欠陥近傍の応力場を得た。その結果を

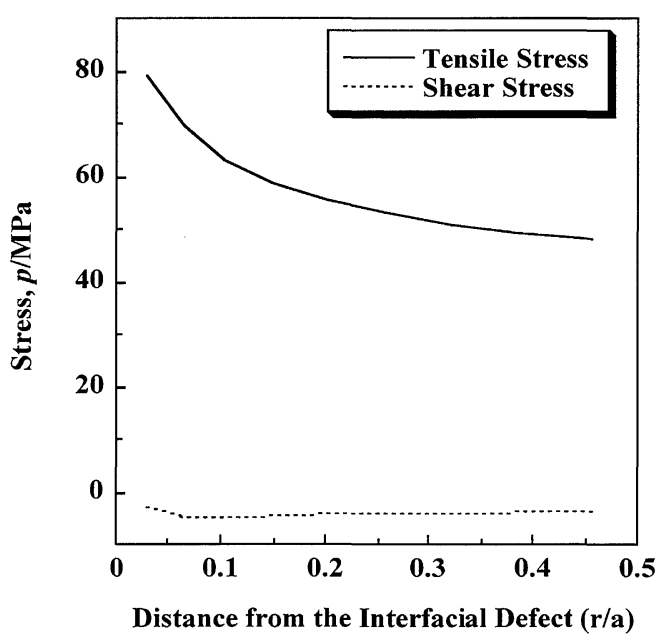

Fig. 10 Calculated tensile and shear stress near the interfacial defect tensile stress normal to the interface without interfacial defect is set up to $40 \mathrm{MPa}$.

Fig. 10 に示した. 引張り成分は界面欠陥の先端で特異性を 持つことが分かる．また，界面欠樎から十分遠いところでは $40 \mathrm{MPa}$ 程度になり，与光た境界条件の検証ができた。一 方, せん断成分は注ぼゼ口に近くモード I の負荷様式を見せ た. 界面欠陥の応力特異性を次式を用いて近似的に界面欠陥 の応力拡大係数を求めた.

$$
\begin{aligned}
& K_{1}=\lim _{r \rightarrow 0} \sqrt{2 r}(\sigma \cos Q+\tau \sin Q) \\
& K_{2}=\lim _{r \rightarrow 0} \sqrt{2 r}(\tau \cos Q-\sigma \sin Q)
\end{aligned}
$$

ここで， $K_{1}, K_{2}$ はそれぞれモード I， モードIIの応力拡大 係数であり, $Q=\varepsilon \log (r /(r+2 a))$ である. $\varepsilon$ は異材間の接 合体の適合性を特性付ける Dunders パラメータ $\beta$ で表され， $\varepsilon=(1 / 2 \pi) \ln ((1-\beta) /(1+\beta))$ のバイメタル定数である. 近 似の結果を Fig. 11 に示した. $K_{1}$ と $K_{2}$ がrがゼ口の近傍で はそれぞれ $0.1 \mathrm{MPa} \cdot \mathrm{m}^{1 / 2}$ とゼ口程度が得られ，ほぼモード 


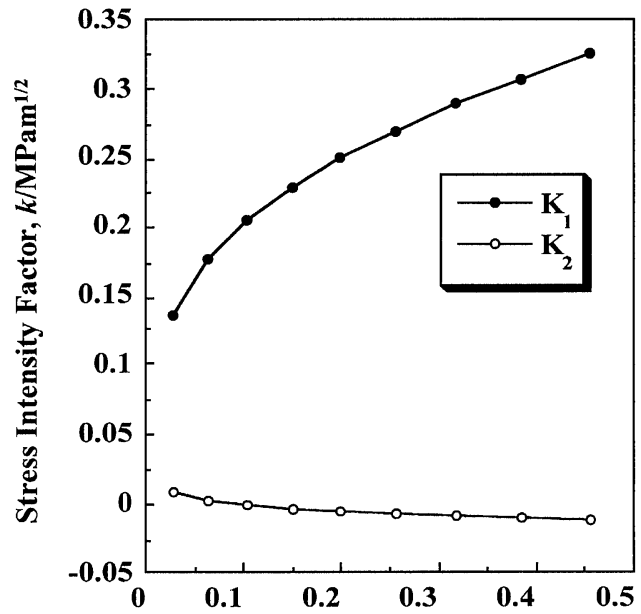

Distance from the Interfacial Defect ( $r / a)$

Fig. 11 Derivation of stress intensity factor from the stress field near the interfacial defect.

Tensile stress normal to the interface without interfacial defect is set up to $40 \mathrm{MPa}$.

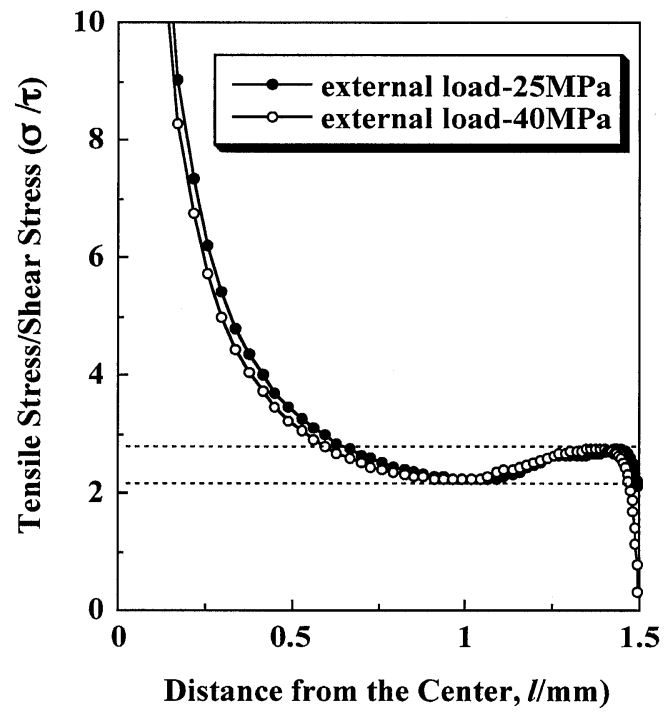

Fig. 12 Tensile to shear stress ratio developed at the interface.

\section{Iによる破壊になっている.}

しかしながら，混合モードの割合は界面欠陥の位置によっ て変わるので，第一段階での応力場を用いて混合モードの補 正を試みた。モードIIの成分がゼロになるのは界面欠陥を中 心設けたことから予想される結果であり，実際の破壊源の 位置に执いては混合モードの割合が異なっていると推定され た。 そこで，界面部に护りる引張り応力に対するせん断応力 の比を計算した(Fig. 12)．破壞源の位置である中心から 1 $\mathrm{mm}$ の距離の前後では, その比は 2 と 3 の間にあることが 図から分かる. 実際の臨界応力拡大係数は上記のせん断応力 によるモードIIの成分を考慮して得られる。しかしながら， 用いた試験片はほぼ全界面に渡って久陷を有しているため, 実際の応力場はそれに影響を受け完全接合を仮定した計算と は異なる，従って，接合面積率の影響および混合モードをよ り正確的に解析するためには，3 次元解析が必要であると考
えられる. 本研究に抢いて, 界面破壊を示し解析に用いた接 合率 0.6 程度の $20 \mathrm{MPa}$ 接合体は極端な場合であり, 実際に はより接合率の高い材料が作製可能でめり，その場合は本解 析による誤差は大幅に減少することが推測される．そのため 予き裂の導入括よび臨界距離, 臨界欠陥大きさ, 最大欠陥大 きさなど特性値23) の測定が必要なはく離試験による解析と 比べ，この論文で提案したアプローチ法は有効であると言兄 る.

\section{5. 結論}

接合条件を変化させ，接合面積率および界面欠陥構造を制 御した $\mathrm{Al} /$ サファイヤ常温接合体の引張り試験抏よび FEM 解析を行い, 以下のことが明らかになった。

(1) 試験片の中心より周辺部で接合面積率が大きいことが 観察された。 その原因は接合圧力がかかったとき，中心部よ り周辺部で高い圧縮応力がかかるためであり，それは計算に よって確かめられた。

(2) 引張り試験時の連続観察から破壊源の位置は試験片の 中心から $1 \mathrm{~mm}$ 程度の距離であった。これは有限要素法に よる界面部応力場の計算拉よび接合体の界面欠陥構造のかね あいによって決まり，予想できる結果であった。

（3）引張り試験和よび有限要素法による数值解析を行うこ とにより, 異材界面に存在する界面欠陥成長クライテリオン の導出方法を提案できた.

最後に本研究は日本学術振興会未来開拓学術研究推進事業 (JSPS-RFTF96P00404)の一環として行われたことを記し 謝意を表する。

\section{文献}

1) T. Suga, T. Fujiwaka and G. Sasaki: 9th Eur. Hybrid Microelec. Con., (1994), 314-321.

2) Y. Kashiba and K. Machida: Journal of JWS, 59(1990), 100104.

3) A. Bartlett and A. G. Evans: Acta metall. mater., 41(1993), 497-504.

4) H. P. Kirchner, J. C. Conway and A. E. Segall: J. Am. Ceram. Soc., 70(1987), 104-109.

5) Y. Iino and G. Elssner: Trans. Jpn. Soc. Mech. Eng., 53(1987), 33-38.

6) T. Suga, Y. Takahashi, H. Takagi, B. Gibbesch and G. Elssner: Acta metall. mater., 40 (1992), S133-S137.

7) H. Funakubo and M. Akaike: J. Japan Inst. Metals, 46(1982), 935-943.

8) J. Ruge: Journal of JWS, 47(1978), 402-408.

9) N. Hosoda, L. Yang, Y. Kyogoku and T. Suga: The journal of Japan Institute for Interconnecting and Packaging Electronic Circuits, 11(1996), 510-513.

10) S. V. Pepper: J. Appl. Phys., 47 (1976), 801-808.

11) H. Conrad and L. Rice: Metall. Trans., 1 (1970), 3019-3029.

12) W. P. Gilbreath: ASTM Spe. Tech. Publ., 431 (1967), 128-148.

13) D. H. Buckley: ASTM Spe. Tech. Publ., 431 (1967), 248-271.

14) D. V. Keller: Wear, 6(1963), 353-365.

15) M. M. Chaudhri: ImechE, C158/87 (1987), 1003-1012.

16) Y. J. Park, M. Enoki, T. Suga and T. Kishi: J. Japan Inst. Metals, 63(1999), 1485-1489.

17) R. Yuuki: KAIMENNORIKIGAKU (Baihuukan), (1993), 1148.

18) D. B. Bogy: J. Appl. Mech., 35(1968), 146-154.

19) M. Y. He, A. G. Evans and J. W. Hutchinson: Acta mater., 
44(1996), 2963-2971.

20) M. C. Tolle and M. E. Kassner: Acta metall. mater., 43(1995), 287-297.

21) A. G. Varias, Z. Suo and C. F. Shih: J. Mech. Phys. Solids, 39 (1991), 963-986.

22) V. Tvergaard: Acta metall., 39(1991), 419-426.

23) Y. J. Park, M. Enoki, T. Suga and T. Kishi: J. Japan Inst. Metals, in press.
24) T. Suga: Materia Japan, 29 (1990), 944-947.

25) Z. Suo, C. F. Shih and A. G. Varias: Acta metall. Mater., 41(1993), 1551-1557.

26) Y. J. Park, M. Enoki, T. Suga and T. Kishi: Proc. 9th International Symposium on Nondestructive Characterization of Materials, ed. by R. E. Green, Jr., Sydney in Australia, (1999), pp. 21-26. 